\title{
BENIGN DUODENO-COLIC FISTULAE
}

\author{
M. J. Grayson,* M.B., M.R.C.P., N. D. O’Connell, † M.B., D.M.R.D. \\ Addenbrooke's Hospital, Cambridge
}

In 1857 Dr. Charles Murchison, ${ }^{15}$ in a review of alimentary fistulae, quoted a case in which 'the duodenum communicated with the colon through the gall bladder, the nature of the disease not being stated'. However, the first fully documented case of benign duodeno-colic fistula which we have been able to trace was reported by Sanderson in $1863 .{ }^{28}$ The majority of the reported fistulae between the duodenum and colon have been malignant and benign duodenocolic fistulae are rare. In a review of the literature we have been able to find only 25 cases (see table). There are some other cases in the literature which we have omitted from the table for the following reasons. We have not included the case reported by Blondeau ${ }^{1}$ (quoted by Clayton and Thornton ${ }^{2}$, as it was thought to be malignant. It would seem that the case reported by Krock ${ }^{6}$ is the same as that of Olson. ${ }^{19}$ Garland and Wyatt ${ }^{4}$ reported a case following surgery for pancreatitis, but the site of the fistula would seem to be in doubt. Judd and Burden ${ }^{5}$ reported two cases of internal biliary fistulae where the duodenum connected through the gall bladder to the colon, but we are not including these two cases, as they were not fully documented. For a similar reason we are not including the two separate cases mentioned by Lyons ${ }^{9}$ and Crill $^{3}$ in the discussion following the case report of Olson. ${ }^{19}$ We describe below two further cases of this uncommon condition and discuss the clinical features and diagnosis.

\section{Case I}

The patient, a 40-year-old male clerk, was admitted on 19.9.58 from the out-patient clinic with a history of diarrhoea and abdominal pain. Two and a half years previously he had had intermittent lower abdominal pain with some looseness of the stools lasting for about a week. Six months later he had a second episode, also lasting for a week. Four months before he presented at the clinic he had a further attack of severe colicky lower abdominal pain, eased by passing flatus and associated with a feeling of abdominal distension. At first he had a normal, formed daily motion, but later the stools became fluid, although only once per day. During this illness he lost $20 \mathrm{lb}$. (9.1 kg.) in weight

* At present at St. George's Hospital, London.

$\uparrow$ At present at Cardiff Royal Infirmary. and had a poor appetite. After five weeks his symptoms subsided until three weeks before he was admitted when, following a meal of mussels, he had a recurrence of the lower abdominal pain and his daily stool became loose. On no occasion had the stool been more frequent than once daily and he had noticed no blood. Two weeks prior to admission he vomited some brown fluid on two occasions and once a small clot of blood. Eight days before admission his stools became formed, three days later his abdominal pain ceased, and for four days he had no bowel action. During this last attack he lost a further $20 \mathrm{lb}$. (9.1 kg.) in weight. He had at no time suffered from dyspepsia.

Previous History. No serious illnesses.

On examination he was an ill-looking man, who had obviously lost weight. His tongue was furred and his mucous membranes were slightly pale. His blood pressure was $11_{5} / 6_{5}$ and there were no cardiac, respiratory or neurological abnormalities. There was no abnormal finding on abdominal examination. Rectal examination was normal. Sigmoidoscopy on 22.9.58 showed a rather dry, granular mucosa which was unduly reddened, but not friable. It was thought that the appearances were abnormal, but that they were not typical of ulcerative colitis. A mucosal biopsy was taken from the sigmoid colon. On histological examination this revealed an excess of inflammatory cells, but no abnormality of the glandular pattern.

Laboratory Investigations. Haemoglobin 12.5 g. per $100 \mathrm{ml}$; mean corpuscular haemoglobin concentration $29.7 \%$; blood film, normochromia and some anisocytosis; white cell count 13,000 per mm. ${ }^{3}$ with $78 \%$ polymorphonuclear neutrophil leucocytes; E.S.R. (Wintrobe) $45 \mathrm{~mm}$. in the first hour; stool culture, no pathogens isolated.

Radiology. On 26.9.58 a barium enema examination demonstrated a fistula between the colon and the upper alimentary tract. There was no other colonic lesion and, in particular, no radiological evidence of ulcerative colitis. A chest radiograph was normal. On 1.10.58 a barium meal examination showed no abnormality of the oesophagus or stomach. The duodenal cap was deformed and an ulcer was present in the second part of the duodenum with kinking of the duodenum and some hold-up of barium at this site. The remainder of the duodenum emptied rapidly and showed a jagged contour. No fistula was seen at this examination. On 6.10.58 a repeat barium enema examination demonstrated a fistula between the region of the ulcer in the second part of the duodenum and the proximal part of the transverse colon (Fig. I).

Course. For the first three days the patient had a low-grade pyrexia of $99.6^{\circ} \mathrm{F}$. $\left(37.6^{\circ} \mathrm{C}\right.$.) and had no bowel action. Thereafter he was apyrexial and had a daily formed motion.

After preliminary phthalyl-sulphathiazole and oral streptomycin, a laparotomy was performed on 7.10 .58 


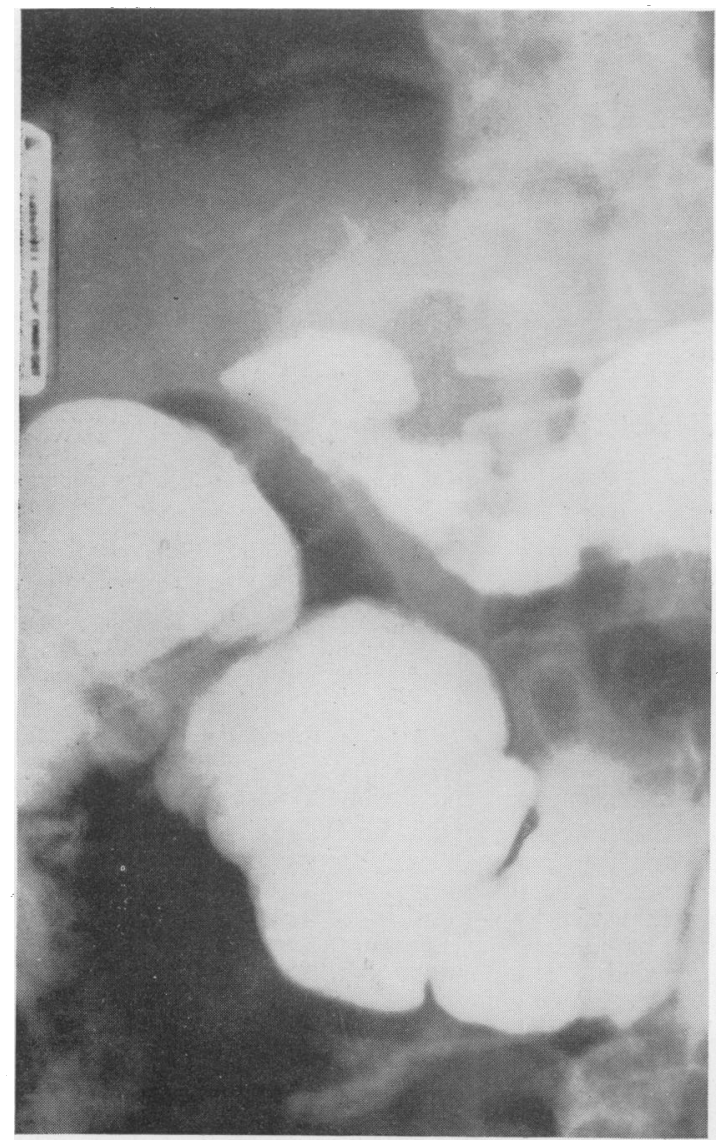

FIG. I.-Case I. Barium enema examination showing filling of the duodenal cap and the distal part of the stomach from the colon.

by Mr. P. H. R. Ghey through a right paramedian incision. The hepatic flexure of the colon was bound to the duodenum by many adhesions. Dissection disclosed a fistulous track from the second part of the duodenum to the region of the proximal transverse colon. This was divided and the colonic opening closed. A Polya gastrectomy was then performed with closure of the duodenal stump just distal to the ulcer.

The post-operative course was uneventful and the patient is now symptom-free and has regained his normal weight.

\section{Case 2}

The patient, a farmer aged 33 years, attended the out-patients' department on 30.6.55, complaining of diarrhoea for seven weeks, peri-umbilical pain on defaecation and loss of weight. He had seven or eight pale motions at night but not by day and there was no slime or blood present in the stool. There was no vomiting. He had lost a lot of weight but was uncertain of the amount. During the year preceding his attendance at clinic he had had several attacks of abdominal pain with slight tenderness in the umbilical region and was admitted to another hospital during one such attack, being diagnosed as a case of colitis. At no time during these attacks was he pyrexial. Five months previously

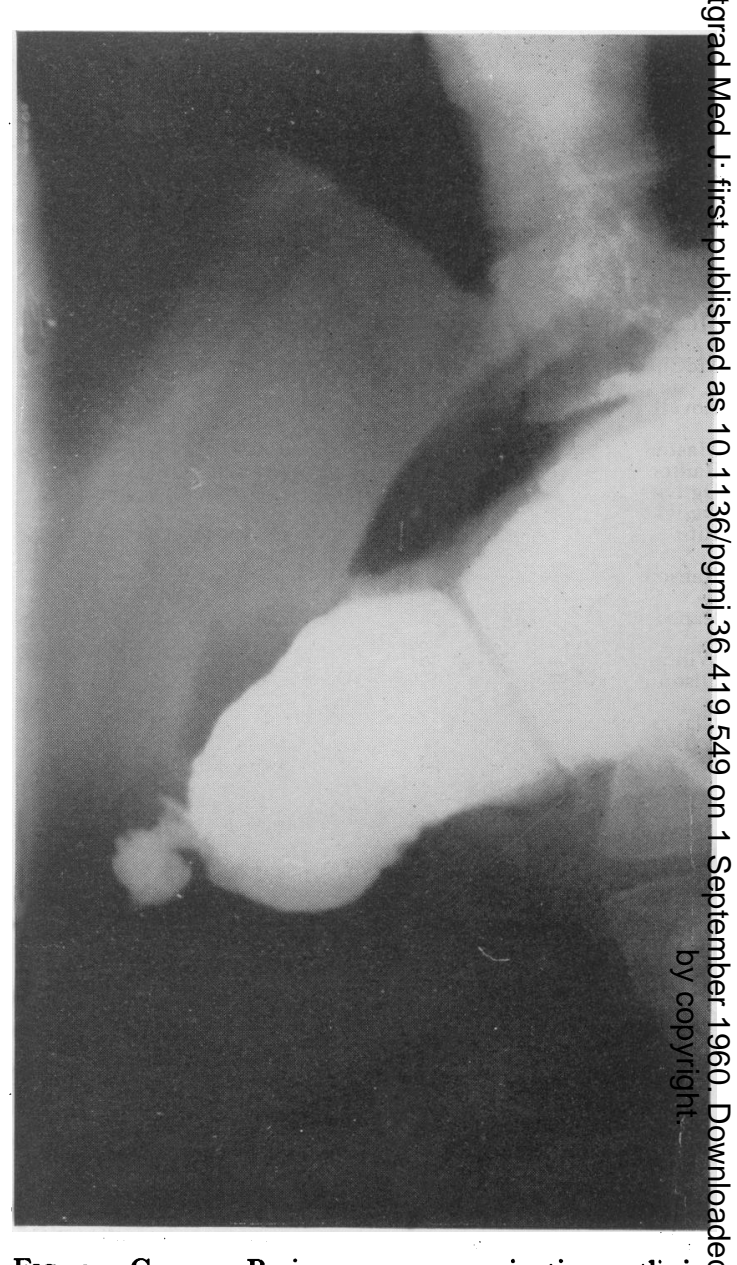

FIG. 2.-Case 2. Barium enema examination outlining the obstruc ive lesion in the proximal transvers colon.

he was treated for a lumbar disc lesion and in February 1955, he had an acute attack of dysentery when Shigella Sonne was isolated from his stools. It was subsequentlz. proved that his whole family were also infected but were symptom-free. Since then, two negative stool culture had been obtained from the patient.

Previous History. No serious illnesses.

On examination the patient was thin, wasted and definitely ill with some distension of the lower abdomen? Peristalsis was active. No anaemia. B.P. $120 / 80$ Rectal examination was normal and sigmoidoscopy was not performed. The stools were clay coloured.

He was admitted to hospital for investigation. barium enema on 15.7.55 showed an obstructive lesion

in the proximal transverse colon (Fig. 2).
At operation on 21.7 .55 the surgeon, Mr. J. F. R Withycombe, found a large mass of inflammatory tissuev involving the caecum and ascending colon with fistulous connection between the duodenum and the region of the hepatic flexure. The fistula was closed an $\mathscr{F}$ a right hemicolectomy was performed with anastomosis of the terminal ileum to the mid-transverse colori. Following the operation he did well until the tenth post operative day when he developed a subcutaneous absces? 


\begin{tabular}{|c|c|c|c|c|c|c|c|c|c|c|c|}
\hline \multirow{2}{*}{\multicolumn{2}{|c|}{ Author }} & \multirow{3}{*}{ Sex } & \multirow{3}{*}{$\frac{\text { Age }}{30}$} & \multirow{3}{*}{ Aetiology } & \multicolumn{4}{|c|}{ Clinical Features } & \multirow{2}{*}{$\begin{array}{l}\text { Method of } \\
\text { Diagnosis }\end{array}$} & \multicolumn{2}{|c|}{ Site of Fistula } \\
\hline & & & & & Pain & Vom. & Diar- & $\begin{array}{l}\text { Wt. } \\
\text { Loss }\end{array}$ & & $\begin{array}{c}\text { Part of } \\
\text { Duodenum }\end{array}$ & Colon \\
\hline Sanderson & 1863 & & & & + & $\stackrel{+}{+}$ & 一 & $?$ & Autopsy & First & Transverse \\
\hline $\begin{array}{l}\text { Rees } \\
\text { Ormandy and }\end{array}$ & 1933 & $\mathbf{F}$ & $\begin{array}{l}62 \\
31\end{array}$ & $\begin{array}{l}\text { ? Typhoid ulcer } \\
\text { Ulcerative colitis }\end{array}$ & $\begin{array}{l}+ \\
+\end{array}$ & $\begin{array}{l}+ \\
+\end{array}$ & $\overline{++}$ & $\stackrel{+}{++}$ & $\begin{array}{l}\text { Operation } \\
\text { Autopsy }\end{array}$ & $\begin{array}{l}\text { Second } \\
\text { First }\end{array}$ & $\begin{array}{l}\text { Transverse } \\
\text { Transverse }\end{array}$ \\
\hline McPeak & $\begin{array}{l}1939 \\
1940\end{array}$ & $\mathbf{M}$ & 58 & Duodenal ulcer & 一 & $\begin{array}{c}+ \\
+\end{array}$ & ++ & + & Barium enema & First & Hepatic \\
\hline McPeak & 1940 & $\mathbf{M}$ & 46 & Duodenal ulcer & + & 一 & ++ & + & Barium enema & Second/ & Transverse \\
\hline McClinton & 1944 & $\mathbf{M}$ & 47 & Duodenal ulcer & + & + & + & + & Barium enema & Second & Transverse \\
\hline Lovell & 1947 & $\mathbf{M}$ & 55 & Cholecystitis & + & + & $?$ & + & Barium enema & First & Transverse \\
\hline $\begin{array}{l}\text { Masters } \\
\text { Railton } \\
\text { Ogilvie } \\
\text { Ogilvie } \\
\text { Rife }\end{array}$ & $\begin{array}{l}1948 \\
1948 \\
1950 \\
1950 \\
1951\end{array}$ & $\begin{array}{l}\mathbf{M} \\
\mathbf{F} \\
\mathbf{F} \\
\mathbf{M} \\
\mathbf{M}\end{array}$ & $\begin{array}{l}40 \\
45 \\
52 \\
54 \\
45\end{array}$ & $\begin{array}{l}\text { Regional ileitis } \\
\text { Duodenal ulcer } \\
\text { Tuberculous gland } \\
\text { Tuberculous gland } \\
\text { Duodenal ulcer }\end{array}$ & $\begin{array}{l}+ \\
\pm \\
-\end{array}$ & $\frac{+}{+}$ & $\begin{array}{l}++ \\
++ \\
++ \\
++\end{array}$ & $\begin{array}{l}++ \\
? \\
++ \\
++ \\
++\end{array}$ & $\begin{array}{l}\text { Operation } \\
\text { Barium meal } \\
\text { Barium meal } \\
\text { Barium enema } \\
\text { Barium meal }\end{array}$ & $\begin{array}{l}\text { Second } \\
\text { First } \\
\text { Third } \\
\text { Third } \\
\text { Second }\end{array}$ & $\begin{array}{l}\text { Transverse } \\
\text { Transverse } \\
\text { Ascending } \\
\text { Ascending } \\
\text { Transverse }\end{array}$ \\
\hline Ransom & 1951 & $\mathbf{M}$ & 28 & Ulcerative colitis & - & 一 & $\stackrel{+}{+}$ & + & Barium enema & Unknown & Transverse \\
\hline Ransom & 1951 & $\mathbf{M}$ & 12 & Ulcerative colitis & $?$ & 一 & (blood) & + & Barium enema & Unknown & Transverse \\
\hline $\begin{array}{l}\text { Winfield } \\
\text { Olson }\end{array}$ & $\begin{array}{l}1951 \\
1951\end{array}$ & $\underset{\mathbf{F}}{\mathbf{M}}$ & $\stackrel{?}{68}$ & ? Duodenal ulcer & $\overline{+}$ & $\frac{\overline{+}}{(\text { faecal })}$ & $\begin{array}{c}+ \\
+ \\
\text { (blood) }\end{array}$ & $\stackrel{?}{+}+$ & $\begin{array}{l}\text { Barium enema } \\
\text { Barium meal } \\
\text { and enema }\end{array}$ & $\begin{array}{l}\text { Third } \\
\text { Second }\end{array}$ & $\begin{array}{l}\text { Sigmoid } \\
\text { Hepatic } \\
\text { flexure }\end{array}$ \\
\hline $\begin{array}{c}\text { Clayton and } \\
\text { Thornton }\end{array}$ & & $\mathbf{M}$ & 48 & $\begin{array}{l}\text { Appendicitis } \\
\text { ? Duodenal ulcer }\end{array}$ & + & & ++ & + & $\begin{array}{l}\text { Barium meal } \\
\text { and enema }\end{array}$ & $\begin{array}{l}\text { Second/ } \\
\text { Third }\end{array}$ & \\
\hline Neville & & $\mathbf{M}$ & $?$ & $\begin{array}{l}\text { Cholecystitis and gall } \\
\text { stones }\end{array}$ & + & $\begin{array}{c}+ \\
\text { (faecal) }\end{array}$ & 一 & 一 & Barium enema & First & $\begin{array}{l}\text { Hepatic } \\
\text { flexure }\end{array}$ \\
\hline $\begin{array}{l}\text { Rosenqvist and } \\
\text { Sjoberg }\end{array}$ & I 955 & $\mathbf{F}$ & 26 & $\begin{array}{l}\text { ? Foreign body } \\
\text { ? Tuberculous gland }\end{array}$ & 一 & & ++ & + & & $\begin{array}{l}\text { Second/ } \\
\text { Third }\end{array}$ & Transverse \\
\hline $\begin{array}{l}\text { Rosenqvist and } \\
\text { Sjoberg }\end{array}$ & 1955 & $\mathbf{M}$ & $6 r$ & $\begin{array}{l}\text { Cholecystitis and gall } \\
\text { stones }\end{array}$ & + & 一 & ++ & + & Barium enema & First & Transverse \\
\hline $\begin{array}{l}\text { Nash and } \\
\text { Daland }\end{array}$ & 1956 & $\mathbf{M}$ & 39 & Duodenal ulcer & + & + & & + & Operation & Second & $\begin{array}{l}\text { Hepatic } \\
\text { flexure }\end{array}$ \\
\hline $\begin{array}{l}\text { Pautler } \\
\text { Michell }\end{array}$ & $\begin{array}{l}1958 \\
1959\end{array}$ & $\begin{array}{l}\mathbf{M} \\
\mathbf{M}\end{array}$ & $\begin{array}{l}72 \\
43\end{array}$ & Duodenal ulcer & $\stackrel{?}{\longrightarrow}$ & 二 & ++ & ++ & $\begin{array}{l}\text { Barium enema } \\
\text { Barium enema }\end{array}$ & $\begin{array}{l}\text { First } \\
\text { Second }\end{array}$ & $\begin{array}{l}\text { Transverse } \\
\text { Transverse }\end{array}$ \\
\hline $\begin{array}{l}\text { Own case I } \\
\text { Own case } 2\end{array}$ & & $\begin{array}{l}\mathbf{M} \\
\mathbf{M}\end{array}$ & $\begin{array}{l}40 \\
33\end{array}$ & $\begin{array}{l}\text { Duodenal ulcer } \\
\text { Regional ileitis }\end{array}$ & + & 二 & $\begin{array}{l}\text { (Dood) } \\
++ \\
++\end{array}$ & + & $\begin{array}{l}\text { Barium enema } \\
\text { Operation }\end{array}$ & $\underset{?}{\text { Second }}$ & $\begin{array}{l}\text { Transverse } \\
\text { Hepatic } \\
\text { flexure }\end{array}$ \\
\hline
\end{tabular}

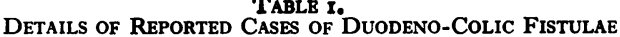

which was drained satisfactorily. He was discharged from hospital a week later, apyrexial, gaining weight and feeling very well. He has had no further complications.

Pathology Report (Dr. R. A. Parker). 'The specimen included caecum, appendix, terminal ileum and the proximal $16 \mathrm{~cm}$. of colon. Six $\mathrm{cm}$. from the ileo-caecal valve, in the narrowed segment, there was considerable thickening of the bowel wall apparently due to submucous fibrosis, without complete destruction of the muscularis mucosae. Outside the bowel wall in this region a certain amount of fibrosis was present in the mesocolon. Similar submucosal thickening was present in the proximal $2 \mathrm{~cm}$. of the appendix and in the distal $4.5 \mathrm{~cm}$. of the ileum. A number of superficial ulcers were also present in the ileum, caecum, appendix and ascending colon with shelving edges and with necrotic, haemorrhagic floors formed by the submucous layer. One such ulcer was situated in the narrowed segment mentioned above and led to a fistula which communicated with the duodenum. The histological appearances were those of a chronic inflammatory lesion, composed mainly of follicular aggregations of lymphocytes with centres composed of epithelial cells'. The lesion was diagnosed as regional ileitis.

\section{Clinical Features \\ Aetiology}

It will be seen from Table I that 20 of the reported cases of benign duodeno-colic fistulae occurred in men, and five in women. Such fistulae can occur at any age ranging in the above reported cases from 12 to 72 years.

As might be expected, duodenal ulceration is the commonest cause of the fistulae, being the cause in nine of the above reported cases and a possible cause in two others. Cholecystitis and ulcerative colitis have each been reported in three cases, and regional ileitis in a further two. Tuberculous glands, typhoid ulceration, appendicitis, duodenal diverticulum and foreign bodies have been postulated as other causes.

\section{Symptomatology}

The typical features of duodeno-colic fistulae include diarrhoea, weight loss, vomiting and abdominal pain. Diarrhoea may be gross and was prominent in 19 out of the 25 reported cases. Understandably, blood was present with the stools in two of the cases of ulcerative colitis, but it was also noted in two other cases where the aetiology was not due to colonic disease. This point is discussed later. In such fistulae it might be expected that the stool would contain undigested food, but this has not been reported.

Weight loss may be severe, ranging from i I lb. 
$(5 \mathrm{~kg}$.) to $84 \mathrm{lb} .(38.2 \mathrm{~kg}$.) in 20 out of the 25 above cases.

Vomiting was not so frequent, being reported in only 12 cases, but when the vomitus was faecal, as it was in half of these cases, it was a useful diagnostic point. Pain was rather non-specific and seemed in most cases to depend on the cause of the fistula.

\section{Diagnosis}

In our first case the provisional diagnosis was that of ulcerative colitis, although the weight loss seemed out of proportion to the severity of the diarrhoea. Although the sigmoidoscopic appearances were abnormal, they were not quite typical of this condition. A mucosal biopsy was taken which showed inflammation, but no diagnostic features of ulcerative colitis. Barium enema showed a duodeno-colic fistula, although this was not demonstrated by a barium meal examination.

In our second case an inflammatory intestinal lesion was suspected on clinical grounds. An obstructive lesion in the ascending colon was shown on barium enema, but the duodeno-colic fistula was not revealed. In this case the diagnosis was made at operation.

In the 25 reported cases, as shown in the table, 19 were diagnosed by barium examination. Of the others, four of the fistulae were demonstrated first at operation and the remaining two at autopsy.

The fistula was demonstrated by barium enema examination in $17(85 \%)$ of the 20 cases where it was performed, whereas 16 barium meal examinations showed the fistulae in only six $(37.5 \%)$ cases. On no occasion did a barium meal examination reveal a fistula which a barium enema had failed to show. These results confirm the contention of Medhurst ${ }^{13}$ that the most useful diagnostic method is barium enema examination. This is probably due to the higher pressure gradient that obtains between the two viscera on barium enema examination.

\section{Treatment}

Operative treatment was performed in 22 out of 25 cases with only one post-operative death, due to a pelvic abscess. Operative procedures included simple ligation or excision of the fistula, sometimes combined with partial or total colectomy or with gastro-enterostomy or partial gastrectomy. At the time of the original reports the 21 patients were in good health. Death ensued in the three patients where operation was not performed.

\section{Discussion}

Diarrhoea and loss of weight are often the presenting complaints in patients with fistulae between the upper alimentary tract and the colon.
Until recent years the explanation of these features was assumed to be the short-circuiting of food and $\frac{3}{8}$ gastric secretions into the colon. Convincing

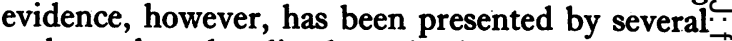
authors that the diarrhoea is due to retrograde $\overrightarrow{\vec{S}^{*}}$ passage of colonic contents through the fistulat with resultant contamination of the small bowel. Lowden ${ }^{8}$ reports an inflammatory jejunitis and $\overline{\bar{c}}$. steatorrhoea in cases of gastro-jejunocolic fistulae. $\mathbb{D}$ Rosenqvist and Sjoberg ${ }^{26}$ also believe that the clinical features of diarrhoea and malabsorption ${ }^{\infty}$ in such fistulae are due to jejunitis with resultant $\vec{\circ}$ rapid passage of food through the small bowel.

In our first case, however, there was histological $\vec{\omega}$ inflammation of the recto-sigmoid mucosa. Whilsto accepting that the main cause of the diarrhoea in 3 . duodeno-colic fistulae is retrograde passage of $\omega$ faeces through the fistulac with resultant jejunitis, we feel that sometimes the pressure in the duo- $\vec{c}$ denum may exceed that of the colon, causing inter- or mittent flow of acid gastric juice into the colon with $\overrightarrow{0}$ resultant colitis and that this may contribute to the diarrhoea. In two other reported cases, without colonic disease, where blood was present in the $\mathcal{\Phi}$ stool, it may be that there was also some acid- $\frac{\mathbb{O}}{\mathbb{O}}$ induced colitis.

\section{Summary}

The literature of benign duodeno-colic fistulae $\frac{8}{2} \overrightarrow{6}$ reviewed and two further cases are added. The condition is rare, the commonest cause being duodenal ulceration. The patient usually complains of diarrhoea. with associated weight loss, which may be severe. The method of choice of diagnosis is by barium enema. The condition is $\frac{Q}{\square}$ usually curable by surgery. The mechanism of the $\overrightarrow{\vec{A}}$ diarrhoea in this condition is discussed.

\section{Acknowledgments}

We should like to thank Dr. A. P. Dick, Dr L. B. Cole, Mr. P. H. R. Ghey and Mr. J. F. R. Withycombe for their kind permission to publish the case reports, and Dr. R. A. Parker for the pathological details. We are grateful to Drs. A. P. Dick and F. R. Berridge for their criticism and advice.

\section{REFERENCES}

1. BLONDEAU, A., DERRIEU and DE LAROQUETTE, D MIRAMOND (1935), cited by Clayton and Thornton. 2. CLAYTON, R. S., and THORNTON, W. L. (1953), Radiology,
60, 832 .

3. CRILL, G. (I95I), quoted by Olson, personal communication.

4. GARLAND, J. G., and WYATT, K. (195I), Rocky Mtn med. N Y., 48,426 .

5. JUDD, E. S., and BURDEN, V. G. (1925), Ann. Surg., 81, 305.

6. KROCK, F. (I95I), in discussion with Ogilvie.

7. LOVELL, D. L. (1947), Sth. Surg., 13, 152.

8. LOWDEN, A. G. R. (1953), Brit. F. Surg., 41, 113.

9. LYONS, C. (I95I), quoted by Olson, personal communication.

1o. MASTERS, H. (1948), f. Mt Sinai Hosp., r5, 264.

I I. McCLINTON, J. B. (1944), Canad. med. Ass. F., 51, 434.

Continued on page 556. 
normal, and this symptom cannot be attributed to continuing glandular fever. Cases 8 and 9 have been included to show the dramatic effect of prednisone subjectively and on the pyrexia, but they are too recent for continued improvement to be reported. We can vouch for the good health of Case ro who is a medical colleague.

\section{Dosage}

Our patients usually started with between 20-60 mg. prednisone daily in divided dosage, to be reduced slowly over the next few weeks. Case 3 might have responded to continued prednisone but we felt bound to change to ACTH for the reasons stated. The apparent superiority of ACTH over oral steroids here, and in other diseases such as ulcerative colitis, may well lie in the matter of effective dosage rather than any specific therapeutic effect. We consider that some authors have not used a sufficient initial dose, nor have they continued the therapy for long enough, and for this reason we would not agree with Mason and Adams ${ }^{7}$ that the speed of recovery is similar to those cases treated with bed rest only. We also feel that the dosage should be lessened slowly, and Cases 2 and 7 demonstrate the relapse which occurs if the drug is withdrawn too quickly.

Until more is known of the cause and mechanisms involved in glandular fever, any interpretation of the apparent beneficial effect of steroids in the treatment of the disease, especially of its complications, can be no more than conjecture. We suspect that the benefit may arise from the known hypo plastic effect of steroids on lymphatic tissue, onhepatitis and encephalitis, as ' antistressor' agents and possibly by reduction of unhelpful antigen-c. antibody responses.

\section{Summary}

Ten patients with glandular fever are reporteç in whom steroid therapy had a beneficial effect $\frac{0}{6}$ three of these had severe complications.

The indications for steroid treatment ares discussed together with suggestions for effectivetherapy.

\section{Acknowledgment}

We wish to thank Dr. Ronald Jones for pero mission to describe three of the cases who were admitted under his care, and Miss London fow secretarial assistance.

\section{REFERENCES}

I. BARRETT, A. M. (I94I), f. Hyg. (Lond.), 4I, 330.

2. CREDITOR, M. C., and MCCURDY, H. W. (1959), Ann. intern. Med., 50, 218.

3. DORAN, J. K., and WEISBERGER, A. S. (1953), Ibid., $38 \mathbb{C}$ 1058

4. FIESE, M. J., CHEN, S., and RADDING, J. (1953), Arch intern. Med., 92, 438.

5. FREEMAN, T., and WAKEFIELD, G. S. (1958), Lancet 883.

6. MANDEL, W., MARILLEY, R. J., and GAINES, L. M (1955), F. Amer. med. Ass., 158, 1021.

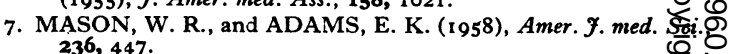

8. NELSEN, R. S., and DARRAGH, J. H. (1956), Amer. F. M? 2I, 26.

\section{NOTICE OF SPECIAL INTEREST TO SUBSCRIBERS:}

\section{-WHY NOT HAVE YOUR COPIES OF THIS JOURNAL BOUND INTO YEARLY VOLUMES?'}

\begin{abstract}
You can have your twelve monthly issues fully bouno in dark green pin head doth. lettered in gilt on spine with name of Journal, Volume Number and year, complete with index at front, for 22s. 6d. post free. A limited number of out of print journals are available to bind into volumes and make your library complete. Price on application giving details of issues required to complete back volumes.
\end{abstract}

the fellowship of postgraduate medicine 60 PORTLAND PLACE, LONDON. W.I

\section{WHY NOT HAVE YOUR JOURNALS BOUND?}

References continued from page 552-M. F. Grayson, M.B., M.R.C.P., and N. D. O'Connell, M.B., D.M.R.D.

12. MCPEAK, C. N. (1940), Radiology, 34, 343.

13. MEDHURST, G. A. (1956), Brit. F. Radiol., 29, $38 \mathrm{r}$.

14. MICHELL, R. C. (1959), Ibid., 32, 55.

15. MURCHISON, C. (1857), Edinb. med. F., 3, 4.

16. NASH, H. E., and DALAND, E. M. (1956), New Engl. $\mathcal{f}$. Med., 254, 1032.

17. NEVILLE, W. E. (1954), Amer. F. Surg., 87, 300.

18. OGILVIE, SIR H. (1950), Ann. Surg., 131, 899.

19. OLSON, J. D. (1951), Amer. Surg., 17, 335.

20. ORMANDY, L., and BARGEN, J. A. (1939), Proc. Mayo Clin., $14,550$.
21. PAUTLER, E. E., WOJDALL, J. C., and GAITHER, J. GN (1958), A.M.A. Arch. intern. Med., 102, 207.

22. RAILTON, S. V. (1948), Canad. med. Ass. F., 59, 267.

23. RANSOM, H. K. (I95I), cited by Rife.

24. REES, C. E. (1933), F. Amer. med. Ass., I00, 496.

25. RIFE, C. S. (195I), Arch. Surg. (Chicago), 62, 876.

26. ROSENQVIST, $H$ and SJOBERG, S. G (I051), Gast enterologia (Basel), 82, 285.

27. ROSENQVIST, H., and SJOBERG, S. G. (1955), Acta chifD scand., 109, 293.

28. SANDERSON (1863), Trans. path. Soc. Lond., I4, 173. 29. WINFIELD, J. M. (195I), cited by Rife. 